\title{
Interaction in vitro between synovial cells and autologous lymphocytes and sera from arthritis patients
}

\author{
T. GHOSE, J. F. WOODBURY, AND M. M. HANSELL
}

From the Rheumatic Diseases Unit and the Departments of Pathology, Medicine, and Anatomy, Dalhousie University, Halifax, Nova Scotia, Canada

SYNOPSIS Synovial cells from patients with rheumatoid arthritis (RA) when grown in vitro in media supplemented with $20 \%$ fetal calf serum failed to show any difference in growth rate, life span, uptake of tritiated thymidine or cellular and nuclear characteristics when compared with synovial cells from patients with osteoarthritis or other joint diseases grown similarly in $20 \%$ serum enriched medium. There was also no evidence that lymphocytes and/or sera from RA patients were more cytotoxic to autologous synovial cells than sera and/or lymphocytes from OA patients. It is unlikely that antisynovial antibodies or lymphocytes from RA patients act as triggers for synovial damage.

Although there is now an increasing body of evidence showing that immune complexes contribute, at least in part, to the development and maintenance of synovial inflammation (Zvaifler, 1973; Ghose, Woodbury, Ahmed, and Stevenson, 1975), it has been postulated that antibodies or cell-mediated immunity against a joint constituent (Roitt, 1971) or a transmissible infectious agent (Warren, Marmor, Liebes and Rosenblatt, 1972; Crocker, Ghose, Rozee, Woodbury, and Stevenson, 1974) might provide a triggering mechanism for the subsequent chain of events. Experimental models (McCluskey, Gell, and Felix-Davies, 1961; Bacon, Jones, Radwanski, and Dumonde, 1969) and several studies in rheumatoid arthritis (RA) patients (MacLennan and Loewi, 1970; Bacon, Bluestone, Cracchiolo, and Goldberg, 1973; Rothenberger and Thiele, 1970; Ghose and Woodbury, 1972; Griffiths and Williams, 1974) support the hypothesis that cell-mediated immunity might play an important role in the production of chronic synovitis in RA. However, other studies using skin testing (Waxman, Lockshin, Schnapp, and Doneson, 1973), non-specific stimulation of lymphocytes in vitro (Plachecka-Gutowska, Zieba-Zak, Brzezinska, and Kopec, 1971), or mixed lymphocyte cultures (Astorga and Williams, 1969) suggest impaired cell-mediated immunity in many RA patients. Although there are several reports demonstrating that lymphocytes from RA patients have no more cytotoxic effect on allogeneic cells than Received for publication 31 December 1974. lymphocytes from apparently healthy individuals (Fraser and Clarris, 1970; MacLennan and Loewi, 1968; White and Peter, 1970), the cytotoxicity of lymphocytes and sera from RA patients to autologous synovial cells does not appear to have been adequately investigated. Using a system capable of demonstrating cytotoxicity of lymphocytes in vitro (McGiven and Ghose, 1968), we report here the results of a study on the interaction of lymphocytes and sera with cultures of autologous synovial cells.

\section{Material and Methods}

PATIENTS AND COLLECTION OF TISSUES

Sterile synovial tissue was obtained during open joint surgery from patients having the following diagnoses: rheumatoid arthritis, osteoarthritis, traumatic arthritis, avascular necrosis of the femoral head, psoriatic arthritis, lupus erythematosus, Reiter's syndrome, osteochondritis, arthritis without definite diagnosis, and amputations for diseases not related to joints. The diagnosis of RA was established according to the American Rheumatism Association criteria by one of us (JFW).

Synovial fluid (SF), obtained by paracentesis from affected joints, was collected into $10 \%$ EDTA under sterile conditions. Samples of peripheral blood for separation of lymphocytes and sera were obtained after synovial cultures had been established, and when the patients were not undergoing immunosuppressive therapy. 


\section{CULTURE METHODS}

Pieces of the superficial layer of synovium of about $1 \mathrm{~mm}^{3}$ were scraped off the suface of sterile fibrofatty synovial samples and grown as primary explant cultures in medium 199 supplemented with $20 \%$ fetal calf serum (GIBCO) in a Falcon flask as described before for other human tissues (Ghose, Nairn, and Cerini, 1968; Ghose and Cerini, 1969). When sheets of cells formed around the explants (usually 7-14 days), the synovial cells were subcultured for varying numbers of passages in medium 199 containing $20 \%$ fetal calf serum. Monolayer cultures of human foreskin fibroblasts (obtained from circumcision specimens) and mouse $L$ cells were also maintained under the same conditions. All synovial and foreskin cultures were tested within 60 days of primary isolation.

\section{CYTOTOXICITY STUDIES}

Lymphocytes were isolated from sterile venous blood with carbonyl iron by means of a mechanical lymphocyte separator (Technicon). Serum $\gamma$-globulin was obtained by precipitation with $33.3 \%$ saturated ammonium sulphate. Cells in synovial fluid were separated by centrifugation $\left(2000 \mathrm{rpm}\right.$ at $4^{\circ} \mathrm{C}$ for 10 minutes).

Seventy-two hours before the addition of serum and/or lymphocytes, all synovial and control foreskin fibroblast and L cell cultures were 'split' and transferred to new flasks. Immediately before testing, the cultures were washed and examined with an inverted microscope, a circular area about $1 \mathrm{~cm}$ in diameter was delineated with a grease pencil on the outer wall of the flask, and the number of cells attached to the flask within this area was counted. Individual culture flasks were then exposed to one of the following: (1) autologous lymphocytes (the ratio of cultured synovial cells to lymphocytes in a flask being approximately $1: 100$ ), (2) lymphocytes plus autologous inactivated serum or serum $\gamma$-globulin, (3) autologous inactivated serum, (4) equal volumes of own inactivated serum and $A B$ group human serum as a source of complement, or (5) AB group human serum only. The final concentration of serum in each flask was $25 \%$. For every patient tested (20 RA and $39 \mathrm{OA}$ ), there were at least two culture flasks in each of the five groups. When there was evidence of reactivity of the patient's lymphocytes and/or serum with autologous synovial cells either by cytotoxicity tests or immunofluorescence, these sera and lymphocytes were tested also on allogeneic synovial cells, foreskin fibroblasts, and mouse $\mathbf{L}$ cells.

Cultures from two RA patients were tested with their own cell free synovial fluid, and control cultures and cultures from two RA and one OA patients were tested with leucocytes separated from their own SF.

Cytotoxicity was assessed every 24 hours for five days by estimating the proportion of trypan blue permeable cells (Ghose et al, 1968) and the proportion of cells which detached from the marked areas of the flask. Clustering of lymphocytes around synovial cells was also noted (Ghose, Norvell, Guclu, Cameron, Bodurtha, and MacDonald, 1972). Sera or lymphocytes were regarded as mildly cytotoxic when the proportion of trypan blue permeable cells was $25-50 \%$ higher than the appropriate control preparations. Metachromasia of synovial cells was assessed by toluidine blue and acid phosphatase by the Gomori lead nitrate method (Gomori, 1952).

Thymidine uptake by the cultured cells was estimated by adding tritiated thymidine (Methyl- $\mathrm{H}^{3}$, New England Nuclear, Boston) in a dose of 10 $\mu \mathrm{Ci} / \mathrm{ml}$ of medium, 2, 4, or 24 hours before fixing the cultures. For autoradiography Ilford K3 emulsion was used.

\section{ELECTRON MICROSCOPY}

Cultures were prepared for electron microscopy by fixation with $2.5 \%$ glutaraldehyde in s- collidine buffer, postfixation in $1 \%$ osmium tetroxide, and embedding in Epon (Brinkley, Murphy, and Richardson, 1967; Douglas and Elser, 1972).

\section{IMMUNOFLUORESCENCE}

The sandwich method was employed using fluorescein isothiocyanate conjugated mono-specific rabbit antisera against human $\operatorname{IgG}, \operatorname{IgM}, \operatorname{IgA}$, and $\mathrm{C3}$ (B1C/BlA) with appropriate controls as described before (Ghose et al, 1968; Ghose and Cerini, 1969; Ghose, Landrigan, Killeen, and Dill, 1974).

\section{Results}

Cultures of human synovial tissue from 48 RA and 105 non-RA patients were successfully grown in vitro. The cultures could be differentiated into three types morphologically: (1) cultures consisting entirely of spindle-shaped fibroblasts arranged in parallel rows, laying down intercellular fibres (fig 1) and identical with the cultures of human foreskin fibroblasts. These cultures probably consisted of the 'classical' fibroblasts present in any connective tissue; (2) cultures containing spindle-shaped fibroblasts, multipolar cells, and often multinucleated giant cells (fig 2); and (3) cultures containing the cells found in type 2 and in addition groups of flat, epithelioid cells (fig 3). In some cultures of types 2 and 3 , cells tended to form villus-like structures in the periphery of the cell sheet (fig 4). Most of the type 2 and 3 cultures contained a varying proportion 


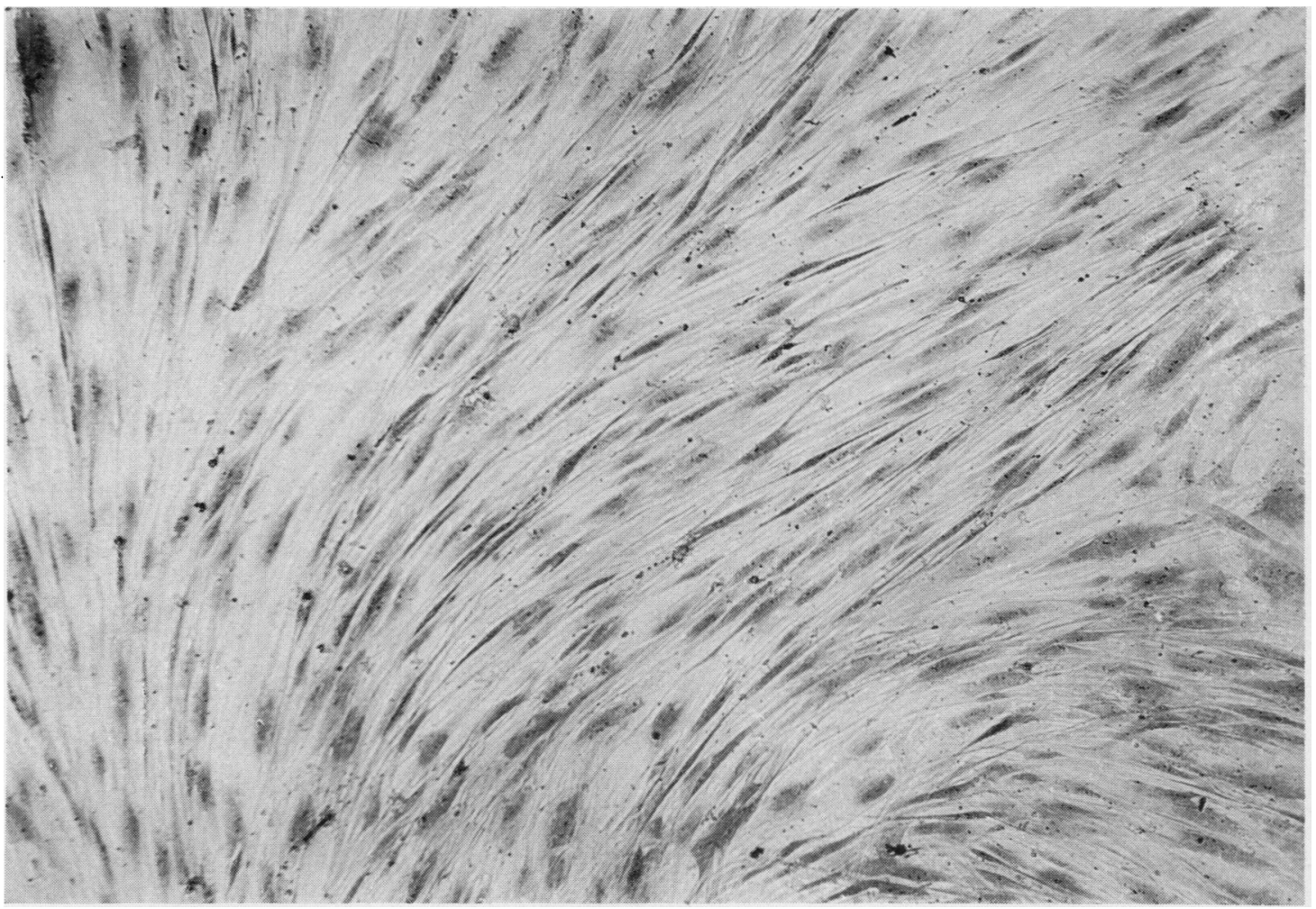

Fig 1 A culture of synovial cells from a RA patient, showing predominance of spindle-shaped fibroblasts arranged in parallel rows (type 1 culture). $(\times 425)$

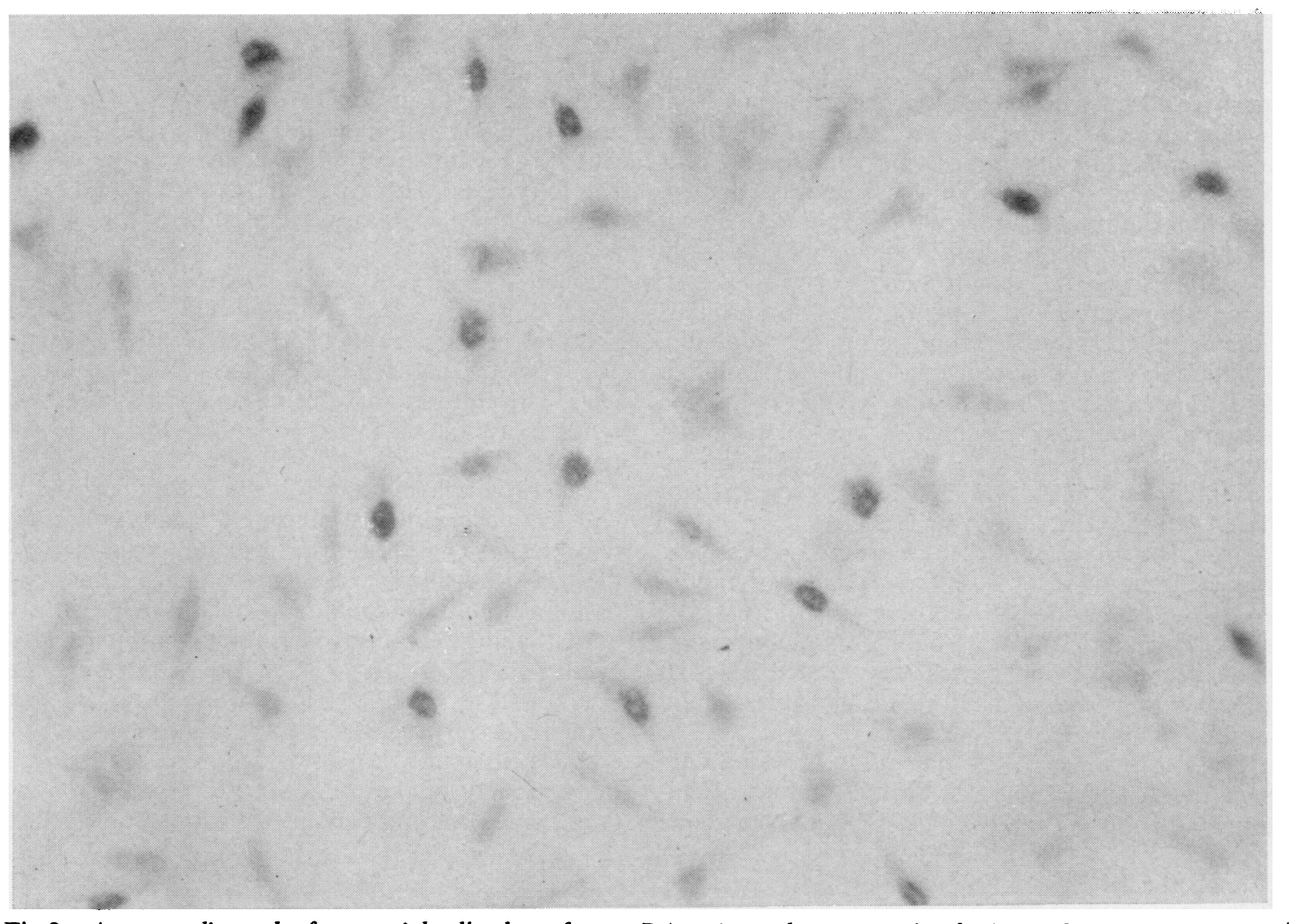

Fig 2 An autoradiograph of a synovial cell culture from a RA patient subsequent to incubation with tritiated thymidine for 24 hours. The culture consists of a mixture of spindle-shaped cells ind multipolar cells (type 2 culture). About $50 \%$ of the cells showed uptake of tritiated thymidine. $(\times 435)$ 


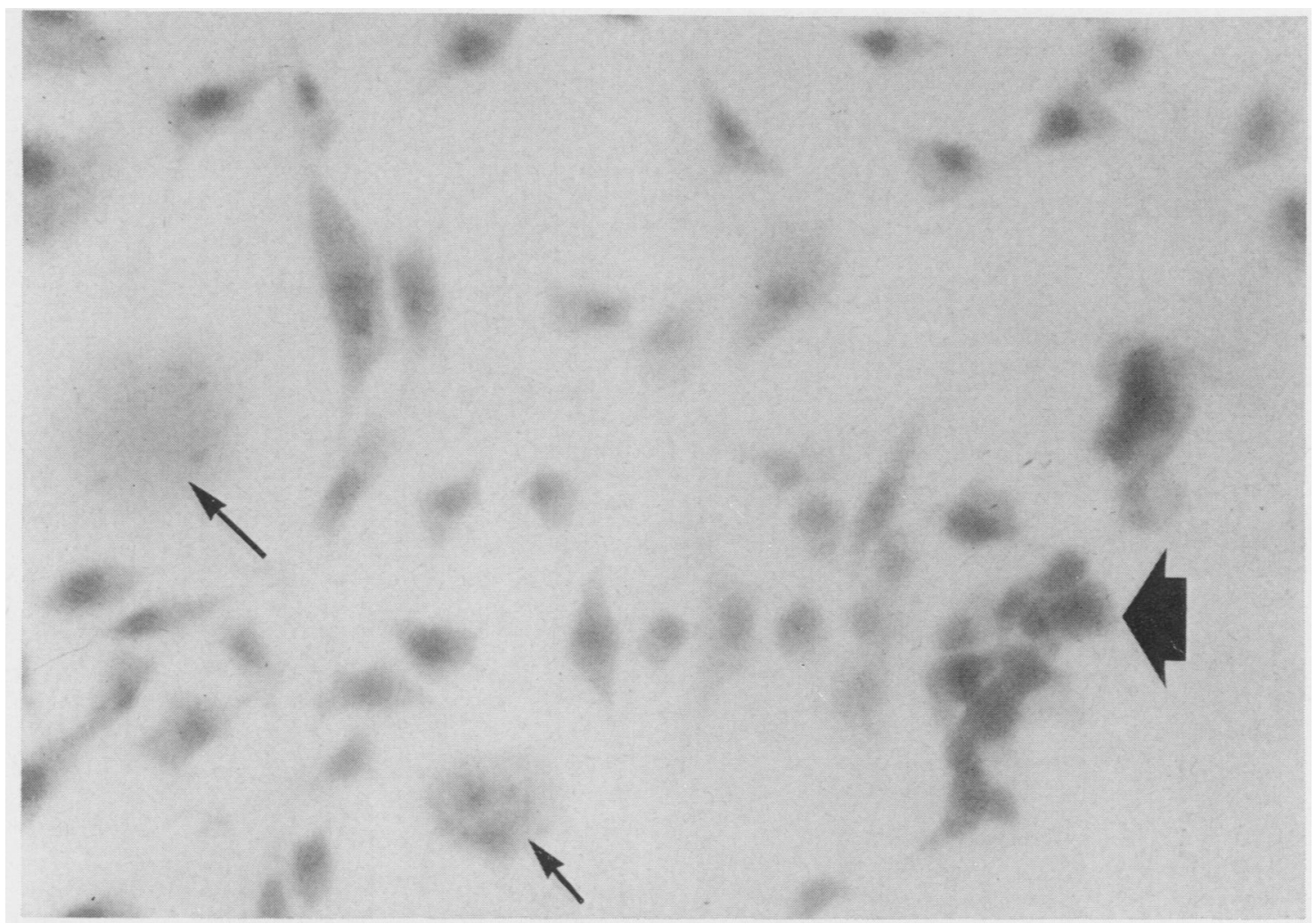

Fig 3 A toluidine blue stained synovial cell culture from a RA patient showing spindle-shaped fibroblasts, multipolar cells, giant cells (marked with thin arrows) and a few closely packed 'epitheloid cells' (marked with a thick arrow) (type 3 culture). Metachromasia could be seen in the cytoplasm of the multipolar and epitheloid cells. $(\times 435)$

Fig 4 A synovial cell culture from a $R A$ patient showing $a$ 'villus' in the periphery of the culture. ( $\times$ 435) 
Fig 5 A synovial cell culture from a RA patient showing acid phosphatase in the cytoplasm when stained by the Gomori method. $(\times 800)$

of cells demonstrating metachromatic substance and/or acid phosphatase in their cytoplasm. Acid phosphatase was found mainly in flat cells or in large multipolar cells (fig 5). There was no increased incidence of giant cells or nuclear abnormalities, nor any difference in tritiated thymidine uptake between established cultures of synovial cells from RA and non-RA patients. There were also no consistent differences either in the initiation of proliferation, or in the life span of the synovial cultures from RA and non-RA patients. Synovium cultures from 12 non-RA and seven RA patients were maintained for over one year, and three RA and five non-RA cultures were maintained for over two years.

Electron microscopic examination of the synovial cultures (type 2) revealed predominantly large flattened cells with lobulated or 'variform' nucleus containing a narrow rim of chromatin in the periphery. Cytoplasm of these cells contained elongated and often branched mitochondria, microfibrils oriented usually along the long axis of the cells, micropinocytotic vesicles, myelin figures, membrane bound inclusions, lipid, droplets, and empty vacuoles. Golgi bodies, sometimes more than one per cell, were also frequently seen. Rough endoplasmic reticulum was not abundant. Desmosomes along the line of contact of contiguous cells were also seen. The majority of the cells thus resembled the type B cells described by Barland, Novikoff, and Hamerman (1962) and also identified by us in the synovial biopsies from both RA and OA patients (fig 6).

Autologous sera and peripheral blood lymphocytes from $20 \mathrm{RA}$ and $39 \mathrm{OA}$ patients were tested for cytotoxic effects on cultured cells. Sera from seven of the RA and nine of the OA patients were mildly cytotoxic to their own and allogeneic syno- 


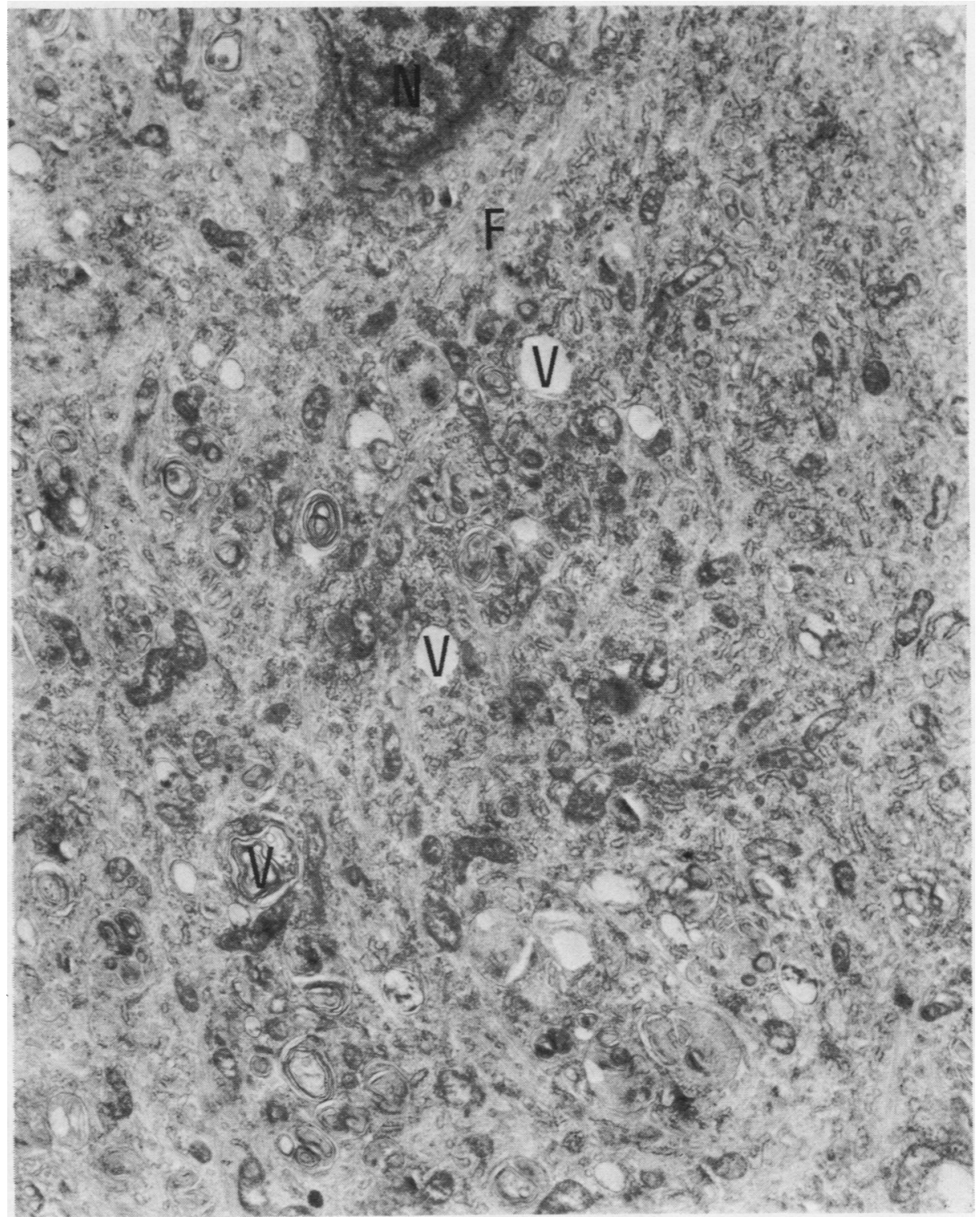

Fig 6 Electron micrograph of a portion of a synovial cell from a type 2 culture. The cytoplasm contains fibrils $(\mathrm{F})$ and many vacuoles $(\mathrm{V})$, some containing membraneous material. $A$ portion of the nucleus $(\mathbb{N})$ and several mitochondria are present. Stained with uranyl acetate and lead citrate. $(\times 19750)$

vial cultures in the presence of complement. Sera from three of these RA patients and one of these OA patients were mildly cytotoxic to cultures of human foreskin fibroblasts and mouse $L$ cells as well.

Peripheral blood lymphocytes from two RA and one OA patient aggregated around their own synovial cells in vitro and were mildly cytotoxic (fig 7).
This cytotoxicity of the lymphocytes was blockaded by autologous serum in two cases (one RA and one OA) and not in the other (RA) (Williams, Lies, and Messner, 1973). Lymphocytes cultured for more than 72 hours with allogeneic synovium or foreskin fibroblasts always showed varying degrees of cytotoxicity to the allogeneic target cells. 
Fig 7 A phase contrast photomicrograph showing clustering of peripheral blood lymphocytes from a RA patient around autologous synovial cells in vitro. $(\times 350)$

In immunofluorescence studies, serum $\gamma$-globulin from six out of 12 RA patients and four out of 25 OA patients tested bound to cultures of their own and allogeneic synovial cells but not to human foreskin fibroblasts or mouse $\mathbf{L}$ cells (fig 8).

\section{Discussion}

Supplementation of the culture medium with about $20 \%$ serum is necessary for proper growth of human synovial cells in vitro '(Bartfeld, 1965; Palmer, 1970.

In keeping with our previous observations on cultures of adult human thyroid (Ghose and Cerini, 1969) and colon epithelium cultures (Ghose et al, 1968), the rate of H3T uptake by synovial cells in medium thus supplemented also depended upon the age of the culture, the $\mathrm{pH}$ and freshness of the medium, cell density, and the time of subculture. It $\rightarrow$ did not depend, as others have reported (Bartfeld, 1965; Castor and Dorstewitz, 1966; Smith, 1971; N Smith and Hamerman, 1969), upon whether the synovium was obtained from RA or non-RA patients. However, due to the variation in the time $\mathrm{\omega}$ needed to form uniform monolayers of cells around $\bar{O}$ the different explants, RA and OA synovial cultures 0 could not be compared on identical days after ex- $\mathbb{D}$ plantation. This could have obscured differences $\stackrel{?}{+}$ between the RA and OA synovial cultures. Spindle- $\underline{T}$ shaped fibroblasts, multipolar, 'epithelioid', and giant cells represent cell types consistently observed $\stackrel{D}{\overparen{D}}$ in human synovial cultures (Bartfeld, 1965; Palmer, $\stackrel{\mathbb{Q}}{\varrho}$ 1970; Castor, Prince, and Dorstewitz, 1961). The o detection of acid phosphatase activity and metachromasia in cultured cells, and the morphology of 


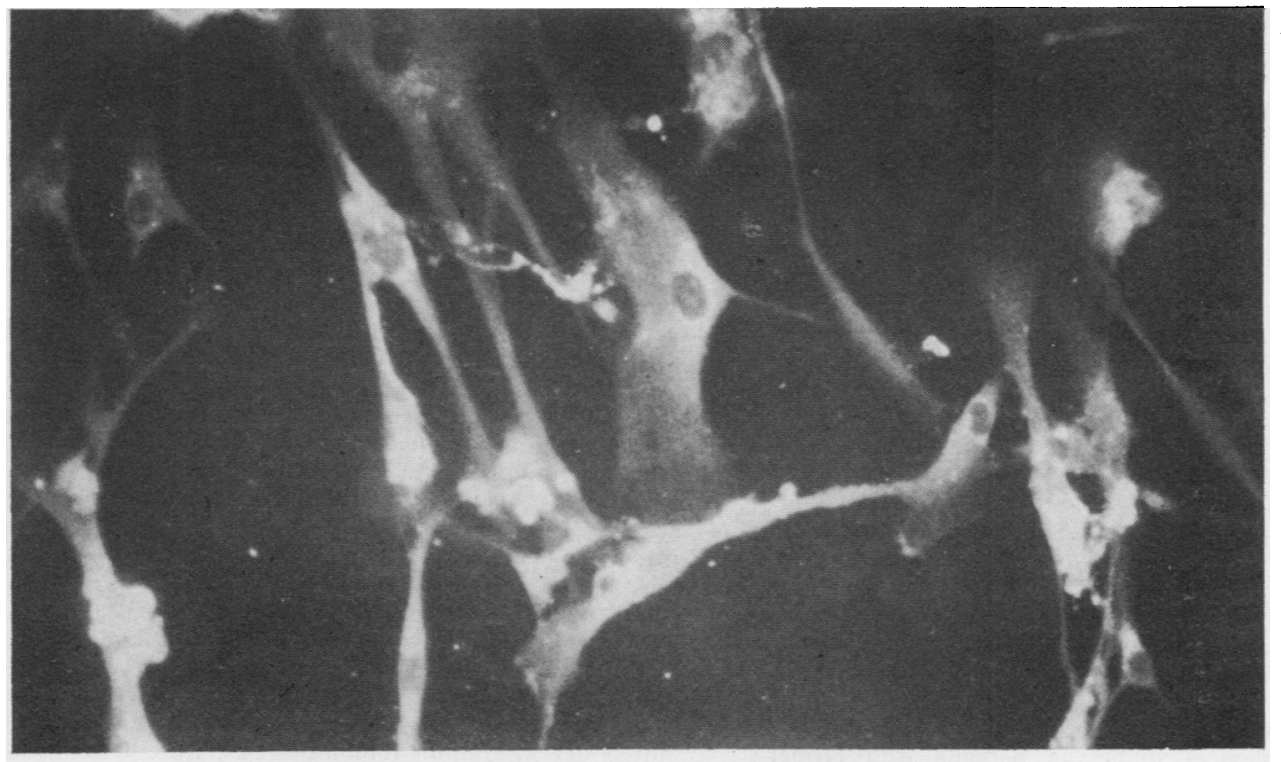

Fig 8 Immunofluorescence photomicrograph of a type 2 culture from an osteoarthritis patient treated first with the patient's serum $\gamma$-globulin and then with fluoresceinated goat antihuman $\gamma$-globulin, showing the binding of the patient's serum $\gamma$-globulin to autologous synovial cells. $(\times 480)$

the several cultured cells observed with the electron microscope (Wynne-Roberts and Castor, 1972) suggest that at least a proportion of the synovial cells in vitro did maintain some of the tissue specific characteristics of synovium (Smith, 1971). Retention of tissue specificity by these synovial cells is further supported by the detection in the blood of some of the OA and RA patients of circulating antibodies and/or lymphocytes which react exclusively with autologous or allogeneic synovial cells but not with any of the other human cell lines or tissues tested. The cytotoxicity of sera from three RA patients and one OA patient to all the cell lines tested is probably of little immunological significance with regard to the pathogenesis of RA, because some normal human sera are known to be cytotoxic to tissue culture cell lines (Ross, 1957; Beno, Lytle, and Edwards, 1969).

Polymorphonuclear leucocytes from synovial fluid are likewise known to damage allogeneic fibroblasts (Hedberg and Källen, 1964) and synovial cells (Fraser and Clarris, 1970) probably not by an immune mechanism, but by rapidly reducing the $\mathrm{pH}$ of the culture medium (Fraser and Clarris, 1970), or as a result of the liberation of lysosomal hydrolytic enzymes (Lundgren, Zukoski, and Möller, 1968).

Because the cytotoxicity of both lymphocytes and antisynovial antibodies could be demonstrated in only a small number of RA patients and it was always mild, it is unlikely that these antibodies or lymphocytes act as initial triggers for synovial damage by other immunological mechanisms.

This investigation was supported by a grant from the Canadian Arthritis and Rheumatism Society. We wish to acknowledge the expert technical help of Mrs B. Stevenson and the participation of the staff of the Dalhousie Rheumatic Diseases Unit. We are grateful to Drs R. H. Yabsley, B. J. Grogano, A. J. Buhr, D. Petrie, and T. M. F. Roberts for referring synovial biopsies for immunological study.

\section{References}

Astorga, G. P. and Williams, R. C., Jr. (1969). Altered reactivity in mixed lymphocyte culture of lymphocytes from patients with rheumatoid arthritis. Arthr. and Rheum., 12, 547-554.

Bacon, P. A., Bluestone, R., Cracchiolo, A., and Goldberg, L. S. (1973). Cell-mediated immunity to synovial antigens in rheumatoid arthritis. Lancet, 2, 699-702.

Bacon, P. A., Jones, E., Radwanski, Z., and Dumonde, D. C. (1969). Cell-mediated immune arthritis in the guinea-pig. (Abstr.) Ann. rheum. Dis., 28, 556.

Barland, P., Novikoff, A. B., and Hamerman, D. (1962). Electron microscopy of the human synovial membrane. J. Cell Biol., 14, 207-220.

Bartfeld, H. (1965). Rheumatoid arthritic and non-rheumatoid synovium in cell culture. Ann. rheum. Dis., 24, 31-39.

Beno, D. W., Lytle, R. J., and Edwards, E. A. (1969). Immunological and biological studies of a cytotoxic com- 
ponent from human sera. J. nat. Cancer Inst., 42, 899-902.

Brinkley, B. R., Murphy, P., and Richardson, L. C. (1967). Procedure for embedding in situ selected cells cultured in vitro. J. Cell Biol., 35, 279-283.

Castor, C. W. and Dorstewitz, E. L. (1966). Abnormalities of connective tissue cells cultured from patients with rheumatoid arthritis. J. Lab clin. Med., 68, 300-313.

Castor, C. W., Prince, R. K., and Dorstewitz, E. L. (1961). 'Epithelial transformation' of human synovial connective tissue cells: cytologic and biochemical consequences. Proc. Soc. exp. Biol., 108, 574-578.

Crocker, J. F. S., Ghose, T., Rozee, K., Woodbury, J. F. L., and Stevenson, B. (1974). Arthritis, deformities, and runting in C5-deficient mice injected with human rheumatoid arthritis synovium. J. clin. Path., 27, 122-124.

Douglas, W. H. J. and Elser, J. E. (1972). A method for in situ embedding of cultured cells grown on plastic surfaces. In vitro, 8, 26-29.

Fraser, J. R. E. and Clarris, B. J. (1970). On the reactions of human synovial cells exposed to homologous leucocytes in vitro. Clin. exp. Immunol., 6, 211-225.

Ghose, T. and Cerini, M. (1969). Persistence of thyroid microsomal and thyroglobulin antigens in primary cultures of human thyroid epithelium. Clin. exp. Immunol., 5, 515 524.

Ghose, T., Landrigan, P., Killeen, R., and Dill, J. (1974). Immunopathological studies in patients with farmer's lung. Clin. Allerg., 4, 119-129.

Ghose, T., Nairn, R. C., and Cerini, M. (1968). Persistence of gastrointestinal-specific antigens in primary cultures of human colon epithelium. Exp. Cell Res., 49, 513-519.

Ghose, T., Norvell, S. T., Guclu, A., Cameron, D., Bodurtha, A., and MacDonald, A. S. (1972). Immunochemotherapy of cancer with chlorambucil-carrying antibody. Brit. med. J., 3, 495-499.

Ghose, T. and Woodbury, J. F. L. (1972). Possible immunological mechanisms of tissue injury in joint disease. In Immune Reactions and Experimental Models in Rheumatic Diseases, pp. 102-105. Toronto University Press, Toronto.

Ghose, T., Woodbury, J. F. L., Ahmad, S., and Stevenson, B. (1975). Immunopathological changes in rheumatoid arthritis and other joint diseases. J. clin. Path., 28, 109-117.

Gomori, G. (1952). In Microscopic Histochemistry: Principles and Practice, p. 273. University of Chicago Press, Chicago.

Griffiths, M. M. and Williams, R. C., Jr. (1974). In vitro peripheral blood and synovial fluid lymphocyte interactions. Arthr. and Rheum., 17, 111-120.

Hedberg, H. and Källén, B. (1964). Studies on mononuclear cells obtained from synovial fluid of patients with different types of arthritis: cytotoxic effect on tissue-cultured human fibroblasts. Acta path. microbiol. scand., 62, 177-188.

Lundgren, G., Zukoski, C. F., and Möller, G. (1968). Differential effects of human granulocytes and lympho- cytes on human fibroblasts in vitro. Clin. exp. Immunol., $3 \stackrel{\stackrel{0}{\overrightarrow{0}}}{\underline{\frac{0}{\sigma}}}$ 817-836.

McCluskey, R. T., Gell, P. G. H., and Felix-Davies, D局 (1961). Experimental allergic arthritis. Fed. Proc., 20, 17 $\stackrel{\oplus}{+}$ McGiven, A. R. and Ghose, T. (1968). Antinuclear factor ine $\mathrm{NZB} / \mathrm{NZW}$ mice: incidence and in vitro effects. Clin. exp흐 Immunol., 3, 657-663.

MacLennan, I. C. M. and Loewi, G. (1968). The effect of peripheral lymphocytes from patients with inflammatorye joint disease on human target cells in vitro. Clin. exp Immunol., 3, 385-391.

MacLennan, I. C. M. and Loewi, G. (1970). The cytotoxic $\overrightarrow{0}$ activity of mononuclear cells from joint fluid. Clin. exp. Immunol., 6, 713-720.

Palmer, D. G. (1970). Dispersed cell cultures of rheumatoid synovial membrane. Acta rheum. scand., 16, 261-270.

Plachecka-Gutowska, M., Zieba-Zak., Brzezinska, B., and Kopec, M. (1971). Cell-mediated immunity in rheumatoidoo arthritis. Ann. Immunol., 3, 35-45.

Roitt, I. M. (1971). Immunological phenomena in rheuma-ن toid arthritis. In Progress in Immunology, edited by B.S Amos, pp. 689-697. Academic Press, New York.

Ross, J. D. (1957). Cytotoxins and cytotoxic antibodies. Ann. N.Y. Acad. Sci., 69, 795-800.

Rothenberger, W. and Thiele, H. G. (1970). In vitro-Studie zur Pathogenese der primär-chronischen Polyarthritis< mittels des Migrations-Inhibitionstests. Klin. Wschr., 48, $\overrightarrow{0}$ 1308-1311.

Smith, C. (1971). Properties of synovial cells in culture. जै J. exp. Med., 134, Suppl. 306-312.

Smith, C. A. and Hamerman, D. (1969). Significance of persistent differences between normal and rheumatoid synovial membrane cells in culture. Arthr. and Rheum., 12. $\overline{\mathrm{O}}$ 639-645.

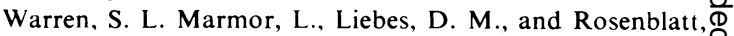
H. M. (1972). An active agent from rheumatoid arthritis synovial tissue. Arch. intern. Med., 130, 899-903.

Waxman, J., Lockshin, M. D., Schnapp, J. J., and Doneson, I. N. (1973). Cellular immunity in rheumatic diseases. $1 . \overline{7}$ Rheumatoid arthritis. Arthr. and Rheum., 16, 499-506.

White, E. and Peter, J. B. (1970). In vitro studies of possible cell-mediated tissue injury in rheumatoid arthritis. Arthr. and Rheum., 13, 358. (Abstr.).

Williams, R. C., Jr., Lies, R. B., and Messner, R. P. (1973). Inhibition of mixed leucocyte culture responses by serum. and $\gamma$-globulin fractions from certain patients with con- $\bigcirc$ nective tissue disorders. Arthr. and Rheum., 16, 597-605. Wynne-Roberts, C. R. and Castor, C. W. (1972). Ultra-o structural comparison of rheumatoid and nonrheumatoid synovial fibroblasts grown in tissue culture. Arthr. and $D$ Rheum., 15, 65-83.

Zvaifler, N. J. (1973). The immunopathology of joint inflammation in rheumatoid arthritis. Advanc. Immunol., 16, $\sigma$ 265-336. 